\title{
Factors Influencing Resilience of Micro Small and Medium Entrepreneur (MSME) during COVID 19 Outbreak in South Sulawesi Province Indonesia
}

\author{
Muhammad Hidayat ${ }^{1}$, Fitriani Latief ${ }^{2}$, DaraAyu Nianty ${ }^{3}$ \\ ShandraBahasoan ${ }^{4}$ AndiWidiawati ${ }^{5}$ \\ ${ }^{12345}$ STIE Nobel Indonesia
}

Article Info

Volume 83

Page Number: $26707-26721$

Publication Issue:

May - June 2020

\begin{abstract}
:
Aim: To find out factors influencing resilience of Micro Small and Medium Entrepreneur MSME entrepreneurs during the worlwide spread of COVID-19 pandemic, this study aims at empirically examine the influence of entrepreneurial personality in utilizing technology and government support for business resilience through crisis management as an intervening variable.

Research design, data and method:This research is a quantitative study analyzing sample of 97 small and medium enterprisesactors in South Sulawesi, Indonesia, chosen by using purposive sampling. The main data in this study is results of questionnaires distributed to respondents which is analyzed by using Partial Least Square (PLS analysis).

Results and Findings: This study proves a positive and significant relationship between entrepreneurship personlity and crisis management. Thereis no significant relationship between utilizing of technology toward crisis management. There is a positive and significant relationship between government supporttoward crisis management. This research also proves a positive and significant influence between crisis management on business resilience.
\end{abstract}

Keywords: Entrepreneurship Characteristic, Technology Utilization, Government Support , Business Resilience

\section{Article History}

Article Received: 11 May 2020

Revised: 19 May 2020

Accepted: 29 May 2020

Publication: 12 June 2020 viruses that infect the respiratory system. This viral infection is called covid-19. Coronavirus causes common cold, amild to moderate upper-respiratory tract illnesses, and even more severe illnesses such asMiddle East Respiratory Syndrome (Mers-CoV) and Severe Acute Respiratory Syndrome (SARS-CoV). This virus first appeared in Wuhan China on December 2019 then it was spreading very fast to various countries, and now it is already consider as a pandemic, devour across the world.
World Health Organization (WHO) states that coronaviruses (cov) are 


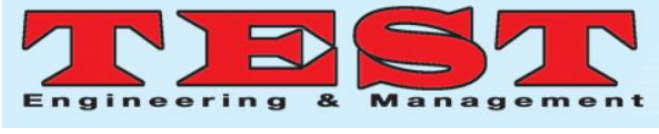

According to worldometers (10/4), globally there were $1,607,595$ cases of covid-19, 95,785 people died and 357,164 people recovered from these cases. This case is still experiencing an upward trend which is shown from several countries. This trend also appears in Indonesia, the case increases quite significant. As of April 10, there were 219 additional cases, so as the total cases were 3,512 in whichthe total cases treated was 2,924, 306 dead and 282 recovering. Moreover,it is predicted that there will be the next surge of this virus.

Variouspolicies began to emerge in responding the case. Start from the implementation of work from home, social distancing and physical distancing, up to a large-scale social restriction (PSBB) is regulated as well. Of course this will leadto the impact on economy of Indonesia. Governmentand public must be ready for what happens if the spread of virus continues to drag on. The impact of corona virus spread occurs in various sectors, both in real sector and stock market. Themost impact is the economy globally in Indonesia where the growth is slowing down.

Itis predicted that if Covid-19 in Indonesia can be overcomed immediately, economic growth will still be above $4 \%$. However, government must also be prepared in case the pandemic persists for another 3-6 months, the situation will be worsen where economic growth estimated at $2.5 \%$ or even $0 \%$. The plague of corona virus also had an impact on the plunge in stock trading. Indonesia Composite Index (ICI) has fallen sharply, even SucorSekuritas analysts explained that ICI could possibly fall down below3000 level (detik.com, 20/3). Anotherimpact is the stability ofrupiah exchange rate which is currently at the level of Rp. 15,900 per US Dollar.It has been pressured at the lowest level on $\mathrm{Rp} 16,575$ per US Dollar on Monday (3/23).

The chronological perspective shows that there are actually interrelationships between the impact of the virus spread in China and Indonesia becauseChina is the largest exporter country in the world and Indonesia is a trading partner of China. Thus, the worsening of trade in China will greatly affect conditions in Indonesia such as the demand for raw materials in China. Because of trading activities in China experienced disruption, a decline in commodity prices occured.

Various impacts arised which is quite hard to bear is a decline of tax revenue, mainly from trade sector. As widely known, taxes have a budgetary function that is one of sources of funds in country development, both central and regional governance. Tax collection from trade sector has large contribution in tax revenue. This is related to the decline of production in China, which is the center of world goods production. It causes obstacles of some supply of raw materials and other goods. Trading volume also experienced disruption which consequently affecting tax revenue.

The disruption ofraw materials supplies greatly affects economic activities for businesses. Because of the hindrance in production activities, many companies experience difficulties due to reduced income so they cannot afford to pay their workers which leads to employment layoff. As a result, many people have difficulties to earn money which finally triggerslow economic growth if this 
pandemic outbreak becomes more protracted.

Institute of Development Economics and Finance (Indef) states that the impact of corona virus on Indonesia's economic growth rate can be traced through the correlation of economic relations between China and Indonesia. A very large correlation in trade and investment between Indonesia and China resulted in a decline in economic growth. This means that China's economy shrink affects the economic downgrowth in Indonesia. Itcan be said that for every 1 percent in Chinese economic growth, the Indonesian economy can be affected by 0.3 percent. Indef projects that China's economic growth will only be around 5 percent in 2020,shrink 1 percent compared to 2019. The magnitude of corona virus(covid-19) effect on economic growth is not only affect Indonesia but also the economic growth of ASEAN region and even the global economy.

It has been around six months that COVID 19 attacked Indonesia, endanger the economy and businesses. However, there is still economic activity by small business owners and some of the medium-sized enterprises of this business group appear to have better resilience.Micro Small and Medium Enterprises (MSME) proven to survive when the multidimensional crisis hit Indonesia in 1998. MSME was even considered as a 'savior of the national economy' at that time. This is in line with what was revealed by Joseph Alois Schumpeter, an American economist, that the economic growth of a country is very dependent on the resilience of MSMEs when facing a crisis.
Nevertheless, currently Ministry of Finance as Indonesia goverment states that the MSME sector has been the most negatively affected. Small businesses have experienced a drastic decline in income due to the implementation of physical distancing. However, opportunities of low sales are not intended for some MSMEs because product sales have been carried out on line systems. The resilience of these MSMEs should be used as a model of entrepreneurial resilience so that it is very important for us to know the extent to which this resilience can be realized in MSME and what factors influence the resilience.

\section{LITERATUREREVIEW MSMEresilience}

Crisis is one of threats to the existence and performance of a business (Boin, 2009) ; (Comfort, 2002); (Williams, Gruber, Sutcliffe, Shepherd, \& Zhao, 2017). Likewise, COVID-19 which is currently happening has become a real threat and challenge to the business world not only in certain regions but all entrepreneurs globally. Currently scientists, academic researchers and all social observers are working hard to be able to provide solutions in order to pass the crisis with good anticipation so that the impact can be controlled. Oneof these efforts is to find out what can be done by business owners in facing the current crisis andhave it as a guide in dealing with crises in the future time(Kuckertz et al., 2020).

Research conducted by (Kuckertz et al., 2020)offersfelicitous information especially about what must be prepared both by individual business owners and the government support system as a regulation to help business existenceof entrepreneursamidst pandemic. 
It also can be a guidelines dealing with similar crises in the future. Itbecomes very important for us to know what factors actually affect business resilience especially for small and medium business sector. These can be used as an illustration to draw conclusion which is beneficial in developing business resilienceas anticipation in confronting a crisis.

To find out the factors that influence business resilience, firstly we must understand what is meant by entrepreneurship in which there are characters that need to be possessed by pre-entrepreneurs. Thesecharacteristics will be the basis of which entrepreneurship character has an influence on business resilience.

According to (Kasali, 2010) one of the unique sources owned by a small and medium scale company is the personality value of an entrepreneur which inherently attached in a person who is the leader of a company. Generally, the value of running a business is the value of entrepreneurship. Echdar, (2013) explained that entrepreneurshipis a creative and innovative ability that is applied as a basis and resources to find opportunities for success. According to him, the creative process is only carried out by people who owned creative and innovative personalities, those people who have entrepreneurial souls, attitudes, and behaviors, with characteristics as follow; (1) full of confidence, indicators are full of confidence, optimistic, committed, disciplined, responsible; Fighting (2) have initiative, the indicators are full of energy, act agile, and active; expand ideas, responsive to change (3) has a motive for achievement, the indicators consist of orientation to results and future insights;
(4) possess a leadership spirit, the indicators are dare to be different, trustworthy, and act tough; (5) dare to take calculated risk (prefer challenge). Thenature of entrepreneurship and entrepreneurial expertise has also been revealed more comprehensively by (Hidayat, Musa, Haerani, \& Sudirman, 2015); (Hidayat \& Yunus, 2019) so that these traits become reference in preparing the entrepreneurship curriculum.

The effectiveness of entrepreneurial traits performed in business highly depends on the situation and conditions experienced by entrepreneurs in their business operations. It is required responsiveness of entrepreneurs to stay survive within these limitations during the spread of covid 19 which led to lockdown and social distancing.

Based on previous research resulting from interviews with business actors in South Sulawesi Indonesia, it was found 53 basic traits of entrepreneurship (Hidayat et al., 2015). Thenafter they were extracted focus on the traits intended at dealing with the crisis,from the many personality traits of entrepreneurs which indicated to have influence on business resilience during the pandemiccovid 19 period can be summarized into 7 important traits to survive in the current crisis conditions, these seven characteristics are: passion to remain sustainable, to maintain hope, passion to struggle as well as hard work, innovation and creativity, customer orientation and remain to maintain quality of product.

Besides the seven characteristics of the entrepreneurs, interviews that have been conducted also show that during pandemic period wherein regional 
lockdowns and physical social distancing, business actors must quickly respond to these obstacles by using technology applications, however, nowadays not all small entrepreneurs understand and are able to use themso that this problem will also greatly affect the resilience of its business caused by communication barriers during pandemic.

The last factor that has an impact on business resilience during pandemic is the governance factor which is demonstrated through the regulation of incentives and financial support in orderto support the activities of small and medium businesses remainto survive during pandemic.

\section{Entrepreneurship Characteristics}

Being an entrepreneur requires more than big ideas. A true entrepreneur is someone who has a unique exellence of traits, skills and characteristics that enables them to overcome obstacles and pursue their dreams at full speed. (Kasali, 2010), Echdar (2012), (Umar, Che Cob, Che Omar, \& Gani Hamzah, 2018) These entrepreneurial characteristics become one of the basic assets of entrepreneurs during pandemic to overcome the challenges they face to keep working and exist. Entrepreneurial toughness is highly dependent on entrepreneurial spirit that is reflected in individual characteristics. The character is the basis of resilience that will lead to the success of an entrepreneur (Fisher, Maritz, \& Lobo, 2016), (Wong, Cheung, \& Venuvinod, 2005), (Ludmila Kozubikova, Jaroslav Belas, Yuriy Bilan, 2015), (Barazandeh, Parvizian, Alizadeh, \& Khosravi, 2015). Individual characteristics will be the basic capital of entrepreneurial competence that is very important for someone in developing and maintaining business in all situations they face (Sánchez, 2012), (Ahmed, Kar, \& Ahmed, 2018).

Research which study about individual traits of entrepreneurial related to the ability to encounter COVID-19 pandemic that can be used as reference is still very limited, most of the research on it was conducted before pandemic. However, there are two major themes in research during this pandemic, the first one is research on how the business world responds to crises and the second is related to the best policy in dealing with crises (Kuckertz et al., 2020). Within thosetwo major themes, researcher will found out how to determine the proper characteristics of individuals in facing crisis caused by COVID-19. Those data was collected through review of data of individual characteristics that has been widely promoted by previous researchers and confirmed further through interviews with business actors from the results of the study. Itwas found the most appropriate individual traits in dealing with pandemic COVID-19 to create business resiliencecalled Entrepreneurial Caracteristic that focuses on business sustainability as seen from 1) Strive, 2) Innovation and Creativity 3) customer orientation. The three characteristics of entrepreneurs are all related to the spirit that will lead an entrepreneur tobe able to increase the resilience of his business.

\section{Technology Utilization}

One of technology utilization in business is the use of digital marketing as a way to market products or services using 
mobile devices. Digitalmarketing is one of the precise and effective ways to reach more consumers in a timely, personal, and relevant manner because all processes carried out can be measured and targeted according to the target audience. Basicallythe use of technology in business is one of ways to manage good relationships with consumer that is profitable and to provide customer comfort.(Kim, Pae, Han, \& Srivastava, 2010)

To remain survive amidst pandemic nowadays, entrepreneurs must be able to work around this. Startingto focus on digital marketing through developing websites which applied ecommerce, social media utilization and sales through e-marketplaces, or they can also find reseller team to sell their products. Actually, in this presence of corona virus pandemic, there are both threats and opportunities. Indeed we have to be able to grasp this opportunity. Business actors in this period of crisis must be able to be keen on looking for opportunities and quickly adapt in order to keeprunning the businessand survive through the crisis phase.

During crisis followed by lockdown policies, social distancing and personal distancing as it is nowis requiring entrepreneurs toquickly adapt with this condition. Therestricted situation influences major changes in consumer behavior trends in shopping where they were used to make purchases traditionally or offline now they turn to do online shopping.Those things certainly becomeschallenge and opportunity that must be addressed properly.

The use of social media marketing has proven to be an effective media to increase customer awareness and satisfaction due to fast and personal service (Yang \& Kankanhalli, 2014). The use of social media marketing which intend to support online sales has started to bloom before the outbreak of COVID- 19 and became even more increased during Covid-19 pandemic. People can not freely go out from home during the implementation of large-scale social restrictions (PSBB) that is regulated in a number of regions in Indonesia. Suggestions to \#stay home followed by work from home (WFH) and school from home guide people to spend more time at home. Therefore, access to the use of internet including social media is increasing, it is an opportunity for entrepreneurs both large scale as well as small and medium enterprises to stay survive by intensifying online sales through social media.

\section{Government Support}

The outbreak of COVID 19 shocked all parties and greatlyimplicated politics and economy of the world nowadays. The most concerned with this was the government who owned the interest in protecting the national economy in general and society in particular. Most of the policy initiatives taken by the government were to protect economic during crisis of COVID-19. The policy targeted the resilience of company, the existing industrial sector and broader economic interests. Those economic rescue efforts aimed at protecting the stability of working status and work productivity as well as thecontinuity of economic activities which is highly needed to protect the people(Kuckertz et al., 2020). 


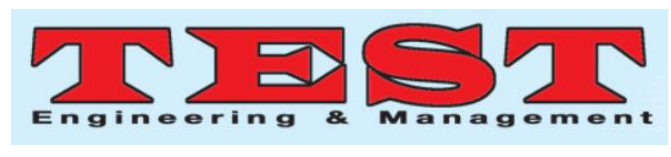

The presence of state in overcoming crises is indispensable.It has become one of research trends during this pandemic period besidesissue of crisis management in the business world that addressed the issue of business resilience (Doern, Williams, \& Vorley, 2019). Research mainstream of policy making tends to see what policies are made by the government in effort to maintain the survival of business world during crisis(Alesch, Arendt, \& Holly, 2009) as well as an in-depth review of what obstacles existed(Runyan, 2006)

In Indonesia, the Government is working earnestly to maintain business resilience mainly in MSME with 5 (five) programs for the sustainability of these businesses those are (1) social assistance which contains family of hope program (PKH), dietary supply, cash assistance, village cash subsidy, exemption or reduction in electricity tariffs and preemployment cards. (2) tax incentives for public. This program reduces the final $\mathrm{PPh}$ rate for MSMEs from $0.5 \%$ to $0 \%$ over a 6-month period. (3) Third, relaxation and restructuring of MSME loans with various program schemes. (4) financing expansion for MSMEs in the form of stimulus for working capital assistance. And (5) ministries, institutions, SOEs and local governments become buffers in the MSME business ecosystem mainly in the initial stages of business consolidation recovery. Based on theoretical foundations and empirical facts related to handling of COVID-19, it is necessary to know to what extent this crisis affects the resilience of entrepreneurs in conducting their business during this crisis period which can be explained in Research Hypothesis.
H1

Characteristic

Influences

Entrepreneurship

Management

Enterpreneurship characteristics will be an important factor for entrepreneurs in running a business (Kasali, 2010); Echdar, 2012; (Fisher et al., 2016); (Wong et al., 2005). The important individual characteristics of entrepreneurs in dealing with crises are reflected in the willingness to continue to stay survive in running a business (sustainability), future goals maintained for success (desire), tireless struggle with no surrender (strive), always work hard to stay exist (Endevour), constantly to innovate and to be creative to meet customer expectations (Innovation and Creativity), always oriented to fullfil customers' needs, desires and expectations (Customer Innovation). These individual characteristics will influence the crisis management of entrepreneurs in dealing with COVID-19 pandemic.

H2 The use of technology influences crisis management

Utilization of technology in pandemic period to anticipate lockdown policies followed by social distancing and personal distancing becomes an essential issue. One effort to stay communicate with customers and to keep selling product is no other effective method than utilizing technology. Thus, the most widely used technology by most people is social media platforms, the utilization of business web and a good knowledge of IT become very influential factors in crisis management conducted by an entrepreneur. This is in line with what was raised by (Yang \& Kankanhalli, 2014) which stated that the use of social media maketing has a strong influence like business performance. 
H3 Government Support Influences crisis management

Government support during crisis will greatly affect the operational activities of MSME, moreover the spread of COVID19 which creates variety of restrictions will greatly impact the operations of the business which mostly rely on direct marketing. Thus, government policies that provide space such as tax relief, funding and other donor will greatly affect business crisis management, as revealed by (Kuckertz et al., 2020) which emphasizes the need for systematic efforts in the form of policies that will help enterpreneurs to survive their business during crisis.

H4 Crisis Management affects the resilience of entrepreneurs

Based on $\mathrm{H} 1, \mathrm{H} 2$ and $\mathrm{H} 3$ above, it is clear that good management of entrepreneurial characteristics, use of technology and government support will create good crisis management which will ultimately affect the level of business resilience of MSME.

Based on the four research hypotheses above, the framework of this research concept can be described as follows:

Picture I. Conceptual Framework of Research

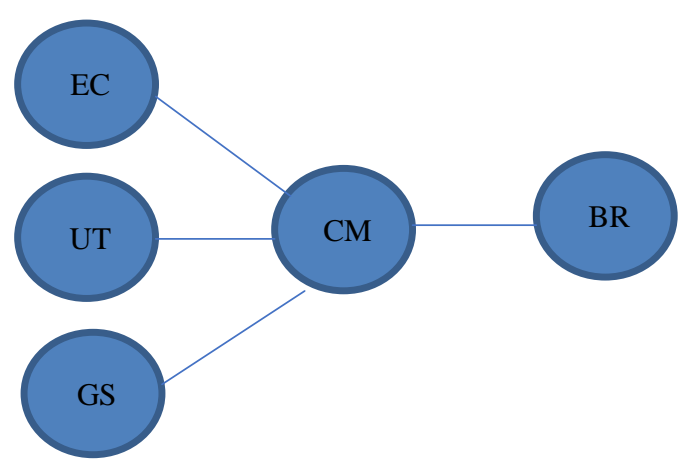

III. RESEARCH DESIGN

\section{ANDMETHODOLOGY}

\section{A. Samples}

Population of this study is small and medium enterprises actors in South Sulawesi Province. Business actors in this sector were chosen considering that MSMEs are one sector that is highly affected from the outbreak of COVID-19 in some reasons (1) MSMEs are businesses that are highly dependent on daily income (2) MSMEs consumers are mostly consumers who did direct purchase. Upon the enactment of lockdown and social distancing policy the direct transaction constrained, hence it will be difficult for MSMEs in running the business (3) There are many MSMEs with no large capital to survive when the lock down and social distancing are enforced for long time period. The sampling technique used in this study was purposive sampling with limitation on MSMEs which had been operated for over 3 years before the outbreak of COVID-19 and it own administrative management and management systems in accordance with business management standards. According to the data, there are 237 samples of MSMEs which meet the requirements.

The sampling is in line withanalysis of Partial Least Squares Structural Equation Modeling (PLS-SEM) Techniques. Minimumsample for MSMEs that appliedMaximum Likelihood Estimation (MLE)is 200 samples (Hair, Henseler, Dijkstra, \&Sarstedt, 2014). Referring to the explanation above, the total respondents participated in the survey were; online there were 211 people, but there were only 97 MSMEsafter beingthrough the screening process. The questionnaire design consisted of two parts, namely 
demography of respondent and variable measurementdata as shownintable2. Data of respondent consisted of gender, age, group of business, while data of variable measurement containsresult of questionnaireanswers from respondents.

\section{B.}

\section{Measurement}

This study uses questionnaire survey to complete survey findings using scale of Likert 1-5 (Strongly disagreeStronglyAgree)such as tests used in science. Measurement of the study results was performed in several stages before data analysis and hypothesis testing were entered. First section; calculate confirmatory factor analysis (CFA) for measuring the viability of measures on dimensions such as; validity and reliability (AVE, Cronbach alpha, and Critical Ratio). Second section; calculate CFA by variables between measurements. The third phase; measures independent variables of dependent variables as shown in figure 1 via moderating effects or hypothesis testing stages.

Table 1: Measurement of Variable

\begin{tabular}{|c|c|c|c|}
\hline Variable & Questionary & & $\begin{array}{l}\text { Major } \\
\text { References }\end{array}$ \\
\hline \multirow{3}{*}{$\begin{array}{l}\text { Entrepreneurship } \\
\text { Characteristic }\end{array}$} & $\begin{array}{l}\text { Extra effort as as a struggle has became principle for } \\
\text { maintaining business to face crisis }\end{array}$ & EP1 & \\
\hline & $\begin{array}{l}\text { To maintain the existence of business innovation and } \\
\text { creativity that continue to be improved, moreover } \\
\text { during current crisis }\end{array}$ & EP2 & \\
\hline & $\begin{array}{l}\text { Trying to always pay attention to customer willingness } \\
\text { and expectations as a main principle in business } \\
\text { including understanding consumers during crisis }\end{array}$ & EP3 & \\
\hline \multirow{3}{*}{$\begin{array}{l}\text { Utilization } \\
\text { Technology }\end{array}$} & $\begin{array}{l}\text { Product sale during crisis have highly utilized social } \\
\text { media marketingthan in normal situations }\end{array}$ & UT1 & \\
\hline & $\begin{array}{l}\text { The development of features and content was further } \\
\text { enhanced during the crisis }\end{array}$ & UT2 & \\
\hline & $\begin{array}{l}\text { Consumers are more intensive in using online } \\
\text { purchasing during crisis than normal era }\end{array}$ & UT3 & \\
\hline \multirow{2}{*}{$\begin{array}{l}\text { Government } \\
\text { Support }\end{array}$} & $\begin{array}{l}\text { During crisis period, Government has supported the } \\
\text { existence of businesses very well }\end{array}$ & GS 1 & \\
\hline & $\begin{array}{l}\text { Government assistance consisting of deferral of credit } \\
\text { payments and deferral of tax payments has greatly } \\
\text { helped cash flow management during crisis }\end{array}$ & GS2 & \\
\hline
\end{tabular}




\begin{tabular}{|c|c|c|}
\hline & $\begin{array}{l}\text { Regulations and policies issued by the government in } \\
\text { handling covid-19 pandemic are still within reasonable } \\
\text { limits and are acceptable to the business world }\end{array}$ & GS3 \\
\hline \multirow{3}{*}{$\begin{array}{l}\text { Crisis } \\
\text { Management }\end{array}$} & $\begin{array}{l}\text { In facing the crisis, we have made careful planning } \\
\text { which was adjusted to internal and external factors }\end{array}$ & CM1 \\
\hline & $\begin{array}{l}\text { In facing crisis we have taken into account the change } \\
\text { of supply pattern and demand patterns as we are trying } \\
\text { to adjust to these changes }\end{array}$ & $\mathrm{CM} 2$ \\
\hline & $\begin{array}{l}\text { In dealing with crisis we have determined the most } \\
\text { important anticipatory steps in managing the effective } \\
\text { and efficient use of resources }\end{array}$ & CM3 \\
\hline \multirow{3}{*}{$\begin{array}{l}\text { Business } \\
\text { Resilince }\end{array}$} & During crisis we still run our business as usual & BR1 \\
\hline & $\begin{array}{l}\text { The revenue we received did not change significant } \\
\text { changes and still fair when the crisis occurred }\end{array}$ & BR2 \\
\hline & $\begin{array}{l}\text { We will continue to run our business because a crisis is } \\
\text { not something to be avoided but it is a challenge that } \\
\text { must be faced }\end{array}$ & BR3 \\
\hline
\end{tabular}

SmartPLS3.0 test equipment, which is comprehensively explained in table 1 . The measurementcriteria for variables and constructs based on AVE values $>0.6$ (Fornell\&Larcker, 1981; Hairet al., 2014). CompositeReliability Value (CR>0.6) (Chin, 1998).Measurement of Cronbachalpha value $>0.5$, R-square, FSquare and measurement of loading-factors as themain formers of the variable (Chin, 1998) which explain in detail in table3.

\section{IV.RESULTS ANDDISCUSSION}

\section{Demography ofRespondent}

Demographically, there were 72 people $(76 \%)$ of respondents in this study which is dominated by male entrepreneurs. This illustrates the composition of entrepreneurs in South Sulawesi that are dominated by male entrepreneurs. There were 64 respondents $(66 \%)$ of the majority of respondents within aged 21 -31 years old. It shows that MSMEswere dominated by startups. Foodand beverage are the most types of businesses that respondents are involved in with the highest average income in the range of 11 to 30 million rupiah per month

Table 2: Data Demography $(\mathrm{N}=97)$

\begin{tabular}{|l|l|l|l|}
\hline Attributes & Item & F & \% \\
\hline Gender & Men & 72 & 74 \\
& Women & 25 & 26 \\
\hline Age (years) & $<20$ year & 5 & 5 \\
& 21- 31 year & 64 & 66 \\
& $>$ 30 year & 28 & 29 \\
\hline
\end{tabular}




\begin{tabular}{|c|c|c|c|}
\hline $\begin{array}{l}\text { Business } \\
\text { Type }\end{array}$ & $\begin{array}{l}\text { F\&B } \\
\text { Hotel } \\
\text { Developer } \\
\text { Construction } \\
\text { Retail } \\
\text { Trading } \\
\text { Transportation }\end{array}$ & $\begin{array}{l}38 \\
8 \\
11 \\
7 \\
13 \\
12 \\
8\end{array}$ & $\begin{array}{l}39 \\
8 \\
11 \\
7 \\
13 \\
12 \\
8\end{array}$ \\
\hline \multirow{3}{*}{$\begin{array}{l}\text { Income / } \\
\text { Per-month } \\
\text { (in million } \\
\text { rupiah) }\end{array}$} & $<10$ million & 32 & 33 \\
\hline & $11-30$ million & 48 & 49 \\
\hline & .30 million & 17 & 18 \\
\hline
\end{tabular}

\section{Statistical Result}

Analysis of data through PLS produces an algorithmic image as shown in figure no 2, the picture explains that in convergence all indicators are stated as valid, this is shown from all indicators that have a value of loading factor $(\chi)>$ : 0.5 . based on these results, the research data analyzed can be continued as credible data to carry out statistical data analysis for next stage.

Figure 2: PLS Analysis

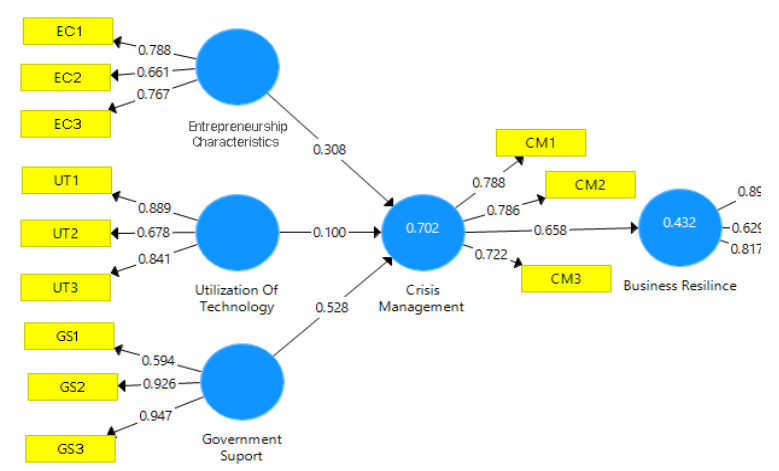

Validity test is not only done through convergent tests but also carried out through discriminant validity test based on AVE values. Statistical data revealed the AVE value of all variables was above 0.5 so that it can be concluded that all items can be used as gauge for the latent variable. Resumes of statistic result can be seen in table The good of fit model in table 3 as follows:

Tabel 3. The Good ofFit Model

\begin{tabular}{|c|c|c|c|c|c|}
\hline Variabel & $\begin{array}{l}\text { Ite } \\
\mathrm{m} \\
\mathrm{s}\end{array}$ & $\begin{array}{l}\text { Val } \\
\text { idit } \\
y\end{array}$ & $\begin{array}{l}\mathrm{A} \\
\mathrm{V} \\
\mathrm{E}\end{array}$ & $\begin{array}{l}\text { Com } \\
\text { posit } \\
\text { e } \\
\text { Relia } \\
\text { bility }\end{array}$ & $\begin{array}{l}\text { Cro } \\
\text { nbac } \\
\text { h } \\
\text { Alfa }\end{array}$ \\
\hline $\begin{array}{l}\text { Entrepre } \\
\text { neurship } \\
\text { Characte } \\
\text { ristic }\end{array}$ & $\begin{array}{l}\mathrm{E} \\
\mathrm{C} \\
1 \\
\mathrm{E} \\
\mathrm{C} \\
2 \\
\mathrm{E} \\
\mathrm{C} \\
3\end{array}$ & $\begin{array}{l}0.7 \\
88 \\
0.6 \\
61 \\
0.7 \\
67\end{array}$ & $\begin{array}{l}0 . \\
54 \\
9\end{array}$ & $\begin{array}{l}0.78 \\
4\end{array}$ & $\begin{array}{l}0.58 \\
8\end{array}$ \\
\hline $\begin{array}{l}\text { Utilizati } \\
\text { on Of } \\
\text { Technol } \\
\text { ogy }\end{array}$ & $\begin{array}{l}\mathrm{U} \\
\mathrm{T} \\
1 \\
\mathrm{U} \\
\mathrm{T} \\
2 \\
\mathrm{U} \\
\mathrm{T} \\
3\end{array}$ & $\begin{array}{l}0.8 \\
89 \\
0.6 \\
78 \\
0.8 \\
41\end{array}$ & $\begin{array}{l}0 . \\
65 \\
3\end{array}$ & $\begin{array}{l}0.84 \\
8\end{array}$ & $\begin{array}{l}0.72 \\
7\end{array}$ \\
\hline $\begin{array}{l}\text { Govern } \\
\text { ment } \\
\text { Support }\end{array}$ & $\begin{array}{l}\text { G } \\
\text { S1 } \\
\text { G } \\
\text { S2 } \\
\text { G } \\
\text { S3 }\end{array}$ & $\begin{array}{l}0.5 \\
94 \\
0.9 \\
26 \\
0.9 \\
47\end{array}$ & $\begin{array}{l}0 . \\
70 \\
2\end{array}$ & $\begin{array}{l}0.87 \\
2\end{array}$ & $\begin{array}{l}0.77 \\
1\end{array}$ \\
\hline $\begin{array}{l}\text { Crisis } \\
\text { Manaje } \\
\text { men }\end{array}$ & $\begin{array}{l}\mathrm{C} \\
\mathrm{M} \\
1 \\
\mathrm{C} \\
\mathrm{M} \\
2\end{array}$ & $\begin{array}{l}0.7 \\
88 \\
0.7 \\
86 \\
0.7 \\
22\end{array}$ & $\begin{array}{l}0 . \\
58 \\
6\end{array}$ & $\begin{array}{l}0.80 \\
9\end{array}$ & $\begin{array}{l}0.69 \\
1\end{array}$ \\
\hline
\end{tabular}




\begin{tabular}{|l|l|l|l|l|l|}
\hline & C & & & & \\
M & & & & \\
& 3 & & & & \\
\hline Business & B & 0.8 & 0. & 0.82 & 0.68 \\
Resilinc & R & 92 & 62 & 7 & 3 \\
e & 1 & 0.6 & 0 & & \\
& B & 29 & & & \\
R & 0.8 & & & \\
2 & 17 & & & \\
B & & & & \\
R & & & & \\
3 & & & & \\
\hline
\end{tabular}

\section{HypothesisResult}

Hypothesis testing results for each of the latent variable relationships presented in table 4 also stated that entrepreneurial personality possessed by entrepreneurs has a positive and significant impact on crisis management (sig. P-value $0.003<0.05$. so hypothesis $\mathrm{H} 1=$ accepted). The utilization of technology applied by entrepreneurs in pandemic period did not have a significant effect on crisis management ( $p$-value 0.186> 0.05, so the hypothesis $\mathrm{H} 2=$ rejected). Government support received by entrepreneurs has a positive and significant effect on crisis management (sig.p-value $0,000<0.01$ so that the hypothesis $\mathrm{H} 3=$ accepted). The crisis management implemented by entrepreneurs has a positive and significant effect on business resilience (sig.p-value $0,000<0.05$ so hypothesis $\mathrm{H} 4$ = accepted).

Table 4: Hypothesis Result

\begin{tabular}{|l|l|l|l|l|}
\hline & $\begin{array}{l}\text { Sam } \\
\text { ple } \\
\text { Mea } \\
\mathrm{n}\end{array}$ & $\begin{array}{l}\text { Std.Dev } \\
\text { iation }\end{array}$ & $\begin{array}{l}\mathrm{T} \\
\text { Stati } \\
\text { stik }\end{array}$ & $\begin{array}{l}\text { P.Va } \\
\text { lue }\end{array}$ \\
\hline Entrepren & 0.29 & 0.103 & 2.98 & 0.00 \\
\hline
\end{tabular}

\begin{tabular}{|c|c|c|c|c|}
\hline $\begin{array}{l}\text { eurship } \\
\text { Characteri } \\
\text { stic }\end{array}$ & 9 & & 4 & 3 \\
\hline $\begin{array}{l}\text { Utilization } \\
\text { Of } \\
\text { Technolog } \\
\text { y }\end{array}$ & $\begin{array}{l}0.10 \\
2\end{array}$ & 0.076 & $\begin{array}{l}1.32 \\
6\end{array}$ & $\begin{array}{l}0.18 \\
6\end{array}$ \\
\hline $\begin{array}{l}\text { Governme } \\
\text { nt Support }\end{array}$ & $\begin{array}{l}0.54 \\
3\end{array}$ & 0.098 & $\begin{array}{l}5.39 \\
9\end{array}$ & $\begin{array}{l}0.00 \\
0\end{array}$ \\
\hline $\begin{array}{l}\text { Crisis } \\
\text { Managem } \\
\text { ent }\end{array}$ & $\begin{array}{l}0.66 \\
7\end{array}$ & 0.055 & $\begin{array}{l}11.9 \\
66\end{array}$ & $\begin{array}{l}0.00 \\
0\end{array}$ \\
\hline
\end{tabular}

\section{Discussion}

The results of this study indicate that entrepreneurship personality and government support have a direct effect on crisis management and crisis management affect business resilience while technology utilization does not significantly influence crisis management. These results explain the facts on the field that in pandemic condition that changes the normal business management, personal resilience which is manifested in entrepreneurial attitude possessed by a businessman becomes very important factor in managing a business. This is in line with theory from (Kasali, 2010) which stated that a businessman who has strong personality will be able to overcome the problems he faces with a mature entrepreneurial spirit.

Support from government is needed by MSMEs, especially in overcoming financial problems and working capital. Government support in the form of relaxation of credit as a legal protection for small and medium entrepreneurs to propose payment delays, debt rescheduling and suspension of tax payments becomes an oasis that at least relieve them in managing cash flow so that there is room for them to 
arrange business strategies in crisis management context during this erratic moment.

Utilization of technology has proven to have no significant effect on crisis management. The use of technology such as the use of WEB, social media marketing and online shopping is indeed dominantly appear during this pandemic. Actually it has been adopted by MSMEs long before the pandemic outbreak thus it is not a new thing even though the intensity has increased. It is considered as habitual and normal inverse with the explode of entrepreneurial spirit which instinctively arises to face something incidental. This is certainly determine the way of managing situations that are urgently needed nowadays likewise government support which is indeed became a demand in effort to maintain business existence.

\section{Managerial Implication:}

This research has practical implications and new perspectives on management in extraordinary conditions. This research shows how management responds to conditions that change various settings in business practices when restrictions occured, limit the business movement and suppress transactions, thus management strategies were created to improve business resilience. From these extraordinary conditions, business actors have learned how to run a business under abnormal conditions and learn how to survive in a completely unprofitable situation.

\section{Theoretical Implication:}

Results of this study are expected to be able to enrich knowledge of science, particularly in management context and theories of business and entrepreneurship. The existence of variables that greatly affect the crisis management and variables which have no effect on management of crisis will be able to encourage further researchers to conduct study mainly related to situations faced by business world in dealing with crises and being a reference as well as anticipation to face similar situations in the future.

\section{CONCLUSION}

Business resilience is strongly influenced by the entrepreneurial spirit possessed by business actors with a strong entrepreneurial spirit, thus an entrepreneur will be able to encounter various situations and struggle to survive confronting challenges afore. Results of this study become a clear mirror for both practitioners as well as researchers and academics that it is very important to develop and foster a spirit of entrepreneurship which is proven to be very useful in entrepreneurship because the soul will not only become a shield in uncertain conditions such as the current pandemic conditions, the entrepreneurial spirit will also be very influential in the development and management of businesses in every situation and condition indeed.

\section{REFERENCES}

1. Ahmed, Y. A., Kar, B., \& Ahmed, H. M. S. (2018). Critical Factors Of Entrepreneurial Competencies For Successfully Managing Micro And Small Enterprise In Ethiopia .7(7), 79$87 . \quad$ https://doi.org/10.9790/487X2007018491

2. Alesch, D. J., Arendt, L. A., \& Holly, J. N. (2009). Managing for long-term recovery in the aftermath of disaster. Fairfax, VA: Public Entity Risk Institute (PERI). 
3. Barazandeh, M., Parvizian, K., Alizadeh, M., \& Khosravi, S. (2015). Investigating the effect of entrepreneurial competencies on business performance among early stage entrepreneurs Global Entrepreneurship Monitor (GEM 2010 survey data). Journal of Global Entrepreneurship Research, 5(1). https://doi.org/10.1186/s40497-0150037-4

4. Boin, A. (2009). The new world of crises and crisis management: Implications for policymaking and research. Review of Policy Research, 26(4), 367-377.

5. Comfort, L. K. (2002). Rethinking security: Organizational fragility in extreme events. Public Administration Review, 62, 98-107.

6. Doern, R., Williams, N., \& Vorley, T. (2019). Special issue on entrepreneurship and crises: business as usual? An introduction and review of the literature. Entrepreneurship \& Regional Development, 31(5-6), 400412.

7. Fisher, R., Maritz, A., \& Lobo, A. (2016). Does individual resilience influence entrepreneurial success. Academy of Entrepreneurship Journal, 22(2), 39-53.

8. Hidayat, M., Musa, C. I., Haerani, S., \& Sudirman, I. (2015). The Design of Curriculum Development Based on Entrepreneurship through Balanced Scorecard Approach. International Education Studies, 8(11), 123. https://doi.org/10.5539/ies.v8n11p123

9. Hidayat, M., \& Yunus, U. (2019). The entrepreneurship learning in industrial 4.0 era (case study in indonesian college). Journal of Entrepreneurship Education, 22(5), 1-15.

10. Kasali, R. (2010). MODUL KEWWIRAUSAHAAN (pp. 23-212). pp. 23-212. Jakarta: Hikmah (PT Mizan Publika).

11. Kim, N., Pae, J. H., Han, J. K., \& Srivastava, R. K. (2010). Utilization of business technologies: Managing relationship-based benefits for buying and supplying firms. Industrial Marketing Management, 39(3), 473484.

12. Kuckertz, A., Brändle, L., Gaudig, A., Hinderer, S., Morales Reyes, C. A., Prochotta, A., ... Berger, E. S. C. (2020). Startups in times of crisis - A rapid response to the COVID-19 pandemic. Journal of Business Venturing Insights, 13, e00169. https://doi.org/https://doi.org/10.1016/j .jbvi.2020.e00169

13. Ludmila Kozubikova, Jaroslav Belas, Yuriy Bilan, P. B. (2015). Personal Characteristics Of Entrepreneurs In The Context Of Perception And Managemet Of Business Risk In The SME Segment. Economics and Sociology, 8(1), 41-54. https://doi.org/10.14254/2071

14. Runyan, R. C. (2006). Small business in the face of crisis: identifying barriers to recovery from a natural disaster 1. Journal of Contingencies and Crisis Management, 14(1), 12-26.

15. SabanEchdar\&MuhSaleh. (2012), Manajemen Entrepreneurship, KiatSuksesMenjadiWirausaha, Kretakupa Print, Makassar.

16. Sánchez, J. (2012). The influence of entrepreneurial competencies on small firm performance. Revista Latinoamericana de Psicologia, 44(2), 
$165-177$.

https://doi.org/10.14349/rlp.v44i2.104 0

17. SenenMachmud (2017) The Effect Of Motivation Entrepreneurship On Business Performance Of SMEs Moderated By Process Innovation. Archives Of Business Research Vol 5 No 8 DOI : 10.14738/abr.58.3585.

18. SiminRadipire\& Watson Ladzoni (2014) The Effect Of Enterpreneurial Intention on Business Performance. Journal Of Government and Regulation Vol 3 Issue 4.

19. SimonaSalyova, JankaTaboreckaPetrova, Gabriela Nedelova, JaroslavDad'o (2015) Effect Of Marketing Orientation On Business Performanc A Study From Slovak Food Stuff Industry. ProcediaEconoic and Finance 34 (2015) 622 - 629

20. Umar, A., Che Cob, C. M. S., Che Omar, C. M. Z., \& Gani Hamzah, M. S. (2018). Determinants of
Entrepreneurial Competencies Development in Small and Medium Enterprises. International Journal of Business and Management, 14(1), 147. https://doi.org/10.5539/ijbm.v14n1p14 7

21. Williams, T. A., Gruber, D. A., Sutcliffe, K. M., Shepherd, D. A., \& Zhao, E. Y. (2017). Organizational response to adversity: Fusing crisis management and resilience research streams. Academy of Management Annals, 11(2), 733-769.

22. Wong, W.-K., Cheung, H.-M., \& Venuvinod, P. K. (2005). Individual entrepreneurial characteristics and entrepreneurial success potential. International Journal of Innovation and Technology Management, 2(03), 277-292.

23. Yang, Y., \& Kankanhalli, A. (2014). The Impact of Social Media Marketing on Online Small Business Performance. PACIS, 63. 